\title{
SENGKETA KONSUMEN DAN TEKNIS PENYELESAIANNYA PADA BADAN PENYELESAIAN SENGKETA KONSUMEN (BPSK)
}

\author{
Oleh : Bustamar* \\ Fakultas Syariah IAIN Bukittinggi \\ Jl. Paninjauan Garegeh - Bukittinggi \\ e-mail: hajibustamar@yahoo.co.id
}

\begin{abstract}
The use of products on goods and services by customer potentially creates conflicts due to material lost suffered by the customers as the result of using particular products. The Acts Number 8 Year 1999 of Customers Protection provides customer with a right to work out any conflicts by consulting a costumer's conflict resolution board (BPSK). The resolution of the conflicts is achieved through such processes as mediations, conciliations and arbitration which involve three elements: government, businessmen, and customers. All verdicts made by BPSK in the form of mediation and are final and legal. However, the arbitration ones are possible to be proceeded to the trials.
\end{abstract}

Kata kunci: sengketa, konsumen, BPSK

\section{PENDAHULUAN}

Perkembangan bisnis barang dan
jasa semakin menunjukkan kemajuan pesat dengan berbagai ragam produk barang dan jasa yang ditawarkan, mulai dari produk dalam negeri maupun luar negeri mudah dijumpai di berbagai macam tempat transaksi (pasar). Dengan pemberlakuan MEA (Masyarakat Ekonomi Asean) pada 2015 ini dipastikan pasar dalam negeri akan dibanjiri oleh produk barang dan jasa yang berasal dari luar Indonesia, terutama negara-negara yang tergabung dalam Asean Economic Commonity (AEC).

Keberadaan produk barang dan jasa di satu sisi dan konsumen di sisi lain merupakan dua sisi yang selalu bersentuhan dalam berbagai transaksi yang dilanjutkan dengan pe- makaian barang dan jasa tersebut. Sebagai negara dengan konsumen terbesar di Asia Tenggara, eksistensi konsumen di Indonesia masih disinyalir berada pada posisi lemah dan rentan terhadap timbulnya berbagai kerugian konsumen sebagai akibat dari pemakaian barang dan jasa. Perkembangan industri dan gerak modal yang cepat menyebabkan produksi barang dan jasa semakin kompleks. Begitu juga dengan informasi di balik proses industri sebagai salah satu faktor persaingan. Hal lain, konsumen golongan bawah mempunyai pilihan yang terbatas hanya untuk barangbarang murah. Mekanisme dan transaksi pasar, tidak selalu adil sehingga sering merugikan konsumen. Pemerintah masih kurang berperan untuk menjadi wasit dalam mengatasi mekanisme pasar yang

* Penulis adalah dosen pada Mata Kuliah Ilmu Hukum Fakultas Syariah IAIN Bukittinggi 
unfair dan cenderung merugikan konsumen.

Argumentasi bahwa konsumen masih berada pada posisi yang lemah dan kondisi ketidakseimbangan antara produsen dan konsumen diantaranya disebabkan oleh kekuatan kapital dan modal, produsen lebih terorganisasi, konsumen lebih individual, produsen diberikan kemudahan-kemudahan oleh pemerintah sedangkan konsumen cenderung tidak, karena dihadapkan dengan berbagai regulasi yang rumit. Kondisi ini menyebabkan konsumen berada pada posisi lemah dan sering menjadi korban dari produk barang dan jasa yang mereka manfaatkan.

Oleh karena itu, gerakan pencerdasan dan perlindungan konsumen, perangkat kelembagaan dan hukum, dan upaya lain agar konsumen bisa mengkonsumsi dengan lebih aman merupakan keharusan, karena perkembangan ekonomi dan industri maju akan menimbukan berbagai dampak negatif yang dapat mengancam hakhak konsumen.

Terabaikannya hak-hak konsumen berpotensi menimbulkan kerugian konsumen yang berujung pada sengketa konsumen. Sengketa konsumen adalah sengketa antara konsumen akhir suatu produk barang dan jasa atau jasa dengan pelaku usaha yang timbul sebagai akibat dirugikannya hak-hak konsumen akibat pemakaian produk barang dan jasa. Tulisan singkat ini akan mencoba menjelaskan tentang apa dan bagaimana sengketa konsumen serta bagaimana teknis penyesaiannya pada Badan Penyelesaian Sengketa Konsumen (BPSK).

\section{PENGERTIAN DAN BATASAN KONSUMEN}

Menurut Hornby:" Konsumen (consumer) adalah seseorang yang membeli barang atau menggunakan jasa". "Seseorang atau suatu perusahaan yang membeli barang tertentu atau menggunakan jasa tertentu". "Sesuatu atau seseorang yang menggunakan suatu persediaan atau sejumlah barang". "Setiap orang yang menggunakan barang atau jasa". Black's Law Dictionary: "One who consumers, individuals who purchase, use, maintain and dispose of product and services", artinya: "seseorang yang mengkonsumsi, individu yang membeli, menggunakan, memelihara dan menggunakan/ menghabis dari produk dan jasa" .

UU Perlindungan Konsumen disingkat (UUPK) tepatnya Pasal 1 angka 2 Undang-undang Nomor 8 Tahun 1999 Tentang Perlindungan Konsumen, menyatakan konsumen adalah setiap orang pemakai barang dan/atau jasa yang tersedia dalam masyarakat, baik bagi kepentingan diri sendiri, keluarga, orang lain, maupun makhluk hidup lain dan tidak untuk diperdagangkan.

Secara umum konsumen dapat dibedakan kepada dua kelompok, yaitu: Pertama, konsumen yang menggunakan barang/ jasa untuk keperluan komersial (intermediate consumer, intermediate buyer, derived buyer, consumer of industrial market). Kedua, konsumen yang mengguna- 
kan barang/ jasa untuk keperluan diri sendiri/ keluarga/ non komersial (ultimate consumer, ultimate buyer, end user, final consumer, consumer of the consumer market).

Konsumen pada kelompok pertama disebut juga dengan konsumen perantara, sedangkan konsumen pada kelompok kedua disebut dengan konsumen akhir. Perbedaan kedua konsumen ini penting dalam kaitannya dengan sengketa konsumen, dimana sengketa konsumen pada dasarnya timbul pada konsumen akhir dan bukan konsumen perantara. Selanjutnya menurut Badan Pembinaan Hukum Nasional, konsumen akhir adalah: "Pemakai akhir dari barang, digunakan untuk keperluan diri sendiri atau orang lain dan tidak diperjual belikan".

Yayasan Lembaga Konsumen Indonesia mendefinisikan konsumen akhir: "Pemakai barang atau jasa yang tersedia dalam masyarakat, bagi keperluan diri sendiri atau keluarganya atau orang lain dan tidak untuk diperdagangkan kembali"

Menurut Fakultas Hukum Universitas Indonesia konsumen akhir adalah: "Setiap orang atau keluarga yang mendapatkan barang untuk dipakai dan tidak untuk diperdagangkan".

Sedangkan pengertian konsumen akhir dalam beberapa regulasi terkait adalah sebagai berikut :

1. Undang-Undang Perlindungan Konsumen India:

"Konsumen adalah setiap orang pembeli barang yang disepakati, menyangkut harga dan cara pembayarannya, tetapi tidak termasuk mereka yang mendapatkan barang untuk dijual kembali atau lain-lain keperluan komersial"

2. Perundang-undangan Australia:

"Setiap orang yang mendapatkan barang tertentu dengan harga yang telah ditetapkan (setinggitingginya A \$. 15,000, atau kalau harganya lebih, maka kegunaan barang tersebut umumnya untuk keperluan pribadi, domestik, atau rumah tangga (normally used for personal, family or household purposes)

3. Undang-Undang Jaminan Produk (Amerika Serikat):

"Setiap pembeli produk konsumen yang tidak untuk dijual kembali, dan pada umumnya digunakan untuk keperluan pribadi, keluarga atau rumah tangga (personal, family or household)

Dari berbagai difinisi di atas dapat disimpulkan bahwa konsumen akhir adalah konsumen yang mengkonsumsi secara langsung produk yang diperolehnya.

\section{PENGERTIAN DAN BATASAN SENGKETA KONSUMEN}

Pada dasarnya tidak seorangpun menghendaki terjadinya sengketa dengan orang lain, tidak terkecuali dalam kegiatan bisnis khususnya antara produsen dan konsumen. Apabila hal ini terjadi, maka mengakibatkan kerugian pihak - pihak yang bersengketa baik yang berada pada posisi yang benar maupun pada posisi yang salah. Walaupun demikian, sengketa di 
antara mereka kadang-kadang tidak dapat dihindari. Hal ini disebabkan karena adanya kesalahpahaman, pelanggaran Undang-undang, ingkar janji, kepentingan yang berlawanan, kerugian salah satu pihak.

Menurut Shidarta sengketa konsumen adalah sengketa berkenaan dengan pelanggaran hak-hak konsumen. Lingkupnya mencakup semua segi hukum baik keperdataan, pidana maupun tata usaha negara. Oleh karena itu tidak digunakan istilah "sengketa transaksi konsumen" karena yang terakhir terkesan lebih sempit, yang hanya mencakup aspek hukum keperdataan saja (Shidarta, 2004: 165).

Sedangkan Az. Nasution mengemukakan, sengketa konsumen adalah setiap perselisihan antara konsumen dengan penyedia produk konsumen (barang dan/atau jasa konsumen) dalam hubungan hukum satu sama lain, mengenai produk konsumen tertentu ( Az. Nasution, 1995: 178).

Sengketa ini dapat menyangkut pemberian sesuatu, berbuat sesuatu, atau tidak berbuat sesuatu sebagaimana diatur dalam Pasal 1233 jo 1234 KUH Perdata atau dapat pula berbagai kombinasi dari prestasi tersebut. Objek sengketa konsumen dalam hal ini dibatasi hanya menyangkut produk konsumen yaitu barang atau jasa yang pada umumnya digunakan untuk keperluan rumah tangganya dan tidak untuk tujuan komersial.

\section{ALTERNATIF PENYELESAIAN SENGKETA KONSUMEN}

Pasal 23 UUPK menyebutkan bahwa apabila pelaku usaha pabrikan dan/atau pelaku usaha distributor menolak dan/atau tidak memberi tanggapan dan/atau tidak memenuhi ganti rugi atas tuntutan konsumen, maka konsumen diberikan hak untuk menggugat pelaku usaha dan menyelesaikan perselisihan yang timbul melalui Badan Penyelesaian Sengketa Konsumen (BPSK) atau dengan cara mengajukan gugatan ke badan peradilan di tempat kedudukan konsumen tersebut.

Hal tersebut senada dengan Pasal 45 UUPK yang menyebutkan :

1. Setiap konsumen yang dirugikan dapat menggugat pelaku usaha melalui lembaga yang bertugas menyelesaikan sengketa antara konsumen dan pelaku usaha atau melalui peradilan yang berada di lingkungan peradilan umum.

2. Penyelesaian sengketa konsumen dapat ditempuh melalui pengadilan atau di luar pengadilan berdasarkan pilihan sukarela pihak yang bersengketa.

3. Penyelesaian sengketa di luar pengadilan sebagaimana dimaksud pada ayat (2) tidak menghilangkan tanggung jawab pidana sebagaimana diatur dalam Undang-undang.

4. Apabila telah dipilih upaya penyelesaian sengketa konsumen di luar pengadilan, gugatan melalui pengadilan hanya dapat ditempuh apabila upaya tersebut dinyatakan tidak berhasil oleh 
salah satu pihak atau oleh para pihak yang bersengketa.

Jadi dalam upaya penyelesaian sengketa konsumen menurut UUPK terdapat dua pilihan, yaitu :

1. Melalui lembaga yang bertugas menyelesaikan sengketa antara konsumen dan pelaku usaha (dalam hal ini BPSK), atau

2. Melalui peradilan yang berada di lingkungan peradilan umum.

Dalam kepustakaan tentang penyelesaian sengketa jalur lembaga yang bertugas menyelesaikan sengketa antara konsumen dan pelaku usaha (dalam hal ini BPSK) disebut jalur nonlitigasi, sedangkan melalui peradilan yang berada di lingkungan peradilan umum atau peradilan agama dalam sengketa syari'ah disebut dengan jalur litigasi.

\section{TEKNIS PENYELESAIAN SENG- KETA KONSUMEN DI BPSK}

\section{Tugas dan Kewenangan BPSK}

BPSK merupakan salah satu lembaga yang dapat dijadikan alternatif pencari keadilan bagi para konsumen yang merasa hak hukumnya dirugikan karena pemakaian produk barang dan jasa. Dalam Pasal 1 angka 11 Undangundang Nomor 8 Tahun 1999 Tentang Perlindungan Konsumen, BPSK adalah badan yang bertugas menangani dan menyelesaikan sengketa antara pelaku usaha dan konsumen.

Secara khusus, fungsi BPSK adalah sebagai alternatif penyelesaian sengketa konsumen di luar pengadilan, dan lembaga ini di- bentuk di kabupaten/kota. Dalam Pasal 3 Keputusan Menteri Perindustrian dan Perdagangan Republik Indonesia Nomor: 350/MPP/Kep/ 12/2001 Tentang Pelaksanaan Tugas dan Wewenang BPSK, adapun tugas dan wewenang BPSK meliputi:

1. Melaksanakan penanganan dan penyelesaian sengketa konsumen dengan cara konsiliasi, mediasi, atau arbitrase;

2. Memberikan konsultasi perlindungan konsumen;

3. Melakukan pengawasan terhadap pencantuman klasula baku;

4. Melaporkan kepada penyidik umum apabila terjadi pelanggaran ketentuan dalam Undangundang Nomor 8 Tahun 1999 tentang Perlindungan Konsumen;

5. Menerima pengaduan baik tertulis maupun tidak tertulis, dari konsumen tentang terjadinya pelanggaran terhadap perlindungan konsumen;

6. Melakukan penelitian dan pemerikasaan sengketa perlindungan konsumen;

7. Memanggil pelaku usaha yang diduga telah melakukan pelanggaran terhadap undang-undang perlindungan konsumen;

8. Memanggil dan menghadirkan saksi, saksi ahli dan/ atau setiap orang yang dianggap mengetahui pelanggaran terhadap Undangundang Nomor 8 Tahun 1999 tentang Perlindungan Konsumen;

9. Meminta bantuan penyidik untuk menghadirkan pelaku usaha, saksi, saksi ahli atau setiap orang sebagaimana dimaksud pada huruf $g$ dan huruf $h$, yang tidak 
bersedia memenuhi panggilan BPSK;

10.Mendapatkan, meneliti dan/atau menilai surat, dokumen, atau alat bukti lain guna penyelidikan dan/atau pemeriksaan;

11. Memutuskan dan menetapkan ada atau tidak adanya kerugian di pihak konsumen;

12. Memberitahukan putusan kepada pelaku usaha yang melakukan pelanggaran terhadap perlindungan konsumen;

13. Menjatuhkan sanksi administratif kepada pelaku usaha yang melanggar ketentuan Undangundang Nomor 8 Tahun 1999 tentang Perlindungan Konsumen.

Anggota BPSK terdiri dari unsur pemerintah, unsur konsumen, dan unsur pelaku usaha. Anggota setiap unsur berjumlah sedikitdikitnya 3 (tiga) orang dan sebanyak-banyaknya 5 (lima) orang. Pengangkatan dan pemberhentian anggota BPSK ditetapkan oleh Menteri. Ketentuan lebih lanjut mengenai pembentukan BPSK diatur dalam Keputusan Presiden Republik Indonesia Nomor 90 Tahun 2001. Adapun mengenai pelaksanaan tugas dan wewenang BPSK diatur dalam Surat Keputusan Menteri Perindustrian dan Perdagangan Nomor. 350/MPP/Kep/12/2001. Untuk pertama kali pembentukan BPSK diatur dalam Surat Keputusan Menteri Perindustrian dan Perdagangan Republik Indonesia Nomor 605/MPP/8/2002 tanggal 29 Agustus 2002 tentang Pengangkatan Anggota BPSK pada pemerintah kota Makassar, kota Palembang, kota Surabaya, kota Bandung, kota
Semarang, kota Yogyakarta dan kota Medan.

Sesuai Pasal 19 ayat (1) UUPK bahwa pelaku usaha bertanggung jawab memberikan ganti rugi atas kerusakan, pencemaran dan/atau kerugian konsumen akibat mengkonsumsi barang dan/atau jasa yang dihasilkan atau diperdagangkan. Ganti rugi tersebut harus dilaksanakan dalam tenggang waktu 7 (tujuh) hari setelah tanggal transaksi. Hal ini sesuai yang ditetapkan dalam Pasal 19 ayat (2) bahwa pemberian ganti rugi dilaksanakan dalam tenggang waktu 7 (tujuh) hari setelah tanggal transaksi. Apabila dalam waktu 7 (tujuh) hari ini ternyata pelaku usaha memberikan ganti rugi, maka tidak akan terjadi sengketa konsumen. Namun, sebaliknya apabila dalam waktu 7 (tujuh) hari ini pelaku usaha tidak memberikan ganti rugi, maka akan terjadi sengketa konsumen. Konsumen yang dirugikan akan melakukan upaya hukum dengan cara menggugat pelaku usaha.

\section{Tatacara Pendaftaran Perkara dan Penyelesaiannya di BPSK}

Setiap konsumen yang dirugikan dapat mengajukan permohonan penyelesaian sengketa konsumen kepada BPSK, baik secara tertulis maupun lisan melalui sekretariat BPSK. Permohonan tersebut dapat juga diajukan oleh ahli waris atau kuasanya apabila konsumen meninggal dunia, sakit atau telah berusia lanjut, belum dewasa, atau orang asing (warga negara asing). Permohonan yang diajukan secara tertulis yang diterima oleh BPSK dikeluarkan bukti tanda terima oleh 
sekretariat BPSK kepada pemohon. Permohonan yang diajukan secara tidak tertulis dicatat oleh sekretariat BPSK dalam suatu format yang disediakan, dan dibubuhi tanda tangan atau cap stempel oleh konsumen, atau ahli warisnya atau kuasanya, (Konsumen yang merasa hak hukumnya dirugikan dalam hal tidak bisa datang sendiri ke BPSK dapat diwakili oleh ahli waris, atau kuasanya dalam keadaan konsumen meninggal dunia, sakit atau telah berusia lanjut sehingga tidak dapat mengajukan pengaduan sendiri baik secara tertulis maupun lisan, sebagaimana dibuktikan dengan surat keterangan dokter dan bukti Kartu Tanda Penduduk (KTP), belum dewasa sesuai dengan peraturan perundang-undangan yang berlaku; atau orang asing (Warga Negara Asing). Lihat lebih lanjut ketentuan Pasal 15 atat (3) Kepmenperindag RI No. 350/MPP/Kep/12/2001 Tentang Pelaksanaan Tugas dan Wewenang BPSK), dan kepada pemohon diberikan bukti tanda terima. Berkas permohonan tersebut, baik tertulis maupun tidak tertulis dicatat oleh sekretariat BPSK dan dibubuhi tanggal dan nomor registrasi. Dalam Pasal 16 Keputusan Menteri Perindustrian dan Perdagangan Republik Indonesia Nomor: 350/MPP/ Kep/12/2001 Tentang Pelaksanaan Tugas dan Wewenang BPSK, permohonan penyelesaian sengketa konsumen secara tertulis harus memuat secara benar dan lengkap mengenai:

1. Nama dan alamat lengkap konsumen, ahli waris atau kuasanya disertai bukti diri;
2. Nama dan alamat lengkap pelaku usaha;

3. Barang atau jasa yang diadukan;

4. Bukti perolehan (bon, kwitansi dan dokumen bukti lain);

5. Keterangan tempat, waktu, dan tanggal diperoleh barang dan jasa tersebut;

6. Saksi yang mengetahui barang dan jasa tersebut diperoleh;

7. Foto-foto barang dan kegiatan pelaksanaan jasa, bila ada.

Dalam hal permohonan diterima, maka dilanjutkan dengan persidangan. Ketua BPSK memanggil pelaku usaha secara tertulis disertai dengan copy permohonan penyelesaian sengketa konsumen, selambat-lambatnya dalam waktu 3 (tiga) hari kerja sejak permohonan penyelesaian sengketa diterima secara benar dan lengkap. Dalam surat panggilan dicantumkan secara jelas mengenai hari, jam, dan tempat persidangan serta kewajiban pelaku usaha untuk memberikan surat jawaban terhadap penyelesaian sengketa konsumen dan disampaikan pada hari persidangan pertama, yang dilaksanakan selambat-lambatnya pada hari kerja ke-7 (tujuh) terhitung sejak diterimanya permohonan penyelesaian sengketa konsumen oleh BPSK. Majelis bersidang pada hari, tanggal dan jam yang telah ditetapkan, dan dalam persidangan majelis wajib menjaga ketertiban jalannya persidangan.

Konsiliasi adalah proses penyelesaian sengketa konsumen di luar pengadilan dengan perantaraan BPSK untuk mempertemukan para pihak yang bersengketa dan penyelesaiannya diserahkan kepada 
para pihak. Majelis dalam menyerahkan sengketa konsumen dengan cara konsiliasi mempunyai tugas:

1. Memangggil konsumen dan pelaku usaha yang bersangkutan;

2. Memanggil saksi dan saksi ahli bila diperlukan;

3. Menyediakan forum bagi konsumen dan pelaku usaha, perihal peraturan perundang-undangan di bidang perlindungan konsumen;

Tata cara penyelesaian sengketa konsumen dengan cara konsiliasi adalah:

1. Majelis menyerahkan sepenuhnya proses penyelesaian sengketa kepada konsumen dan pelaku usaha yang bersangkutan, baik mengenai bentuk maupun jumlah ganti rugi;

2. Majelis bertindak sebagai konsiliator;

3. Majelis menerima hasil musyawarah konsumen dan pelaku usaha dan mengeluarkan keputusan;

Mediasi adalah proses penyelesaian sengketa konsumen di luar pengadilan dengan perantaraan BPSK sebagai penasihat dan penyelesaiannya diserahkan kepada para pihak. Dalam persidangan dengan cara mediasi, majelis dalam menyelesaikan sengketa dengan cara mediasi, mempunyai tugas:

1. Memanggil konsumen dan pelaku usaha yang bersengketa;

2. Memanggil saksi dan saksi ahli bila diperlukan;
3. Menyediakan forum bagi konsumen dan pelaku usaha yang bersengketa;

4. Secara aktif mendamaikan konsumen dan pelaku usaha yang bersengketa;

5. Secara aktif memberikan saran atau anjuran penyelesaian sengketa konsumen sesuai dengan peraturan perundang-undangan di bidang perlindungan konsumen.

Tata cara penyelesaian sengketa konsumen dengan cara mediasi adalah:

1. Majelis menyerahkan sepenuhnya proses penyelesaian sengketa konsumen dan pelaku usaha yang bersangkutan, baik mengenai bentuk maupun jumlah ganti rugi;

2. Majelis bertindak aktif sebagai mediator dengan memberikan nasihat, petunjuk, saran, dan upaya-upaya lain dalam menyelesaikan sengketa;

3. Majelis menerima hasil musyawarah konsumen dan pelaku usaha dan mengeluarkan kekuatan;

Dalam Pasal 1 angka 11 Keputusan Menteri Perindustrian dan Perdagangan Republik Indonesia Nomor: 350/MPP/Kep/12/ 2001 Tentang Pelaksanaan Tugas dan Wewenang BPSK, arbitrasi adalah proses penyelesaian sengketa konsumen di luar pengadilan yang dalam hal ini para pihak yang bersengketa menyerahkan sepenuhnya penyelesaian sengketa kepada BPSK. Dalam penyelesaian sengketa konsumen dengan cara arbitrasi, para pihak memilih arbitrator dari 
anggota BPSK yang berasal dari unsur pelaku usaha, unsur pemerintah dan konsumen sebagai anggota majelis. Arbitrator yang dipilih oleh para pihak, kemudian memilih arbitrator ketiga dari anggota BPSK yang berasal dari unsur pemerintah sebagai ketua majelis. Di dalam persidangan wajib memberikan petunjuk kepada konsumen dan pelaku usaha yang bersangkutan. Dengan izin ketua majelis, konsumen dan pelaku usaha yang bersangkutan dapat mempelajari semua berkas yang berkaitan dengan persidangan dan membuat kutipan seperlunya.

Pada hari persidangan 1 (pertama), ketua majelis wajib mendamaikan kedua belah pihak yang bersengketa, dan bilamana tidak tercapai perdamaian, maka persidangan dimulai dengan membacakan isi gugatan konsumen dan surat jawaban pelaku usaha. Ketua majelis memberikan kesempatan kepada konsumen dan pelaku usaha yang bersengketa untuk menjelaskan halhal yang dipersengketakan.

Pada hari persidangan 1 (pertama) sebelum pelaku usaha memberikan jawabannya, konsumen dapat mencabut gugatannya dengan membuat surat pernyataan. Dalam hal gugatan dicabut oleh konsumen, maka dalam persidangan, pertama majelis wajib mengumumkan bahwa gugatan dicabut. Apabila dalam proses penyelesaian sengketa konsumen terjadi perdamaian antara konsumen dan pelaku usaha yang bersengketa, majelis membuat putusan dalam bentuk penetapan perdamaian.
Dalam hal pelaku usaha dan konsumen tidak hadir pada hari persidangan 1 (pertama) majelis memberikan kesempatan terakhir kepada konsumen dan pelaku usaha untuk hadir pada persidangan 2 (kedua) dengan membawa alat bukti yang diperlukan. Persidangan ke 2 (kedua) diselenggarakan selambatlambatnya dalam waktu 5 (lima) hari kerja terhitung sejak hari persidangan 1 (pertama) dan diberitahukan dengan surat panggilan kepada konsumen dan pelaku usaha oleh sekretariat BPSK. Bilamana pada persidangan ke 2 (dua), konsumen tidak hadir, maka gugatannya dinyatakan gugur demi hukum, sebalikmya bila pelaku usaha yang tidak hadir, maka gugatan konsumen dikabulkan oleh majelis tanpa kehadiran pelaku usaha.

Hasil penyelesaian sengketa konsumen dengan konsiliasi atau mediasi dibuat dalam perjanjian tertulis yang ditanda tangani oleh konsumen dan pelaku usaha. Perjanjian tertulis dikuatkan dengan keputusan majelis yang ditandatangani oleh ketua dan anggota majelis. Begitu juga, hasil penyelesaian konsumen dengan cara arbitrasi dibuat dalam bentuk putusan majelis yang ditandatangani oleh ketua dan anggota majelis. Putusan majelis adalah putusan BPSK. Dalam Pasal 40 Keputusan Menteri Perindustrian dan Perdagangan Republik Indonesia Nomor: 350/MPP/Kep/12/ 2001 Tentang Pelaksanaan Tugas Dan Wewenang BPSK, putusan BPSK dapat berupa: 
1. Perdamaian;

2. Gugatan ditolak; dan

3. Gugatan dikabulkan.

Dalam hal gugatan dikabulkan, maka amar putusan ditetapkan kewajiban yang harus dilakukan oleh pelaku usaha. Kewajiban tersebut berupa pemenuhan:

1. Ganti rugi;

2. Sanksi administratif berupa penetapan ganti rugi paling banyak Rp. 200.000.000 (dua ratus juta rupiah), sebagaimana dituangkan dalam Pasal 14 Keputusan Menteri Perindustrian dan Perdagangan Republik Indonesia Nomor: 350/MPP/Kep/12/ 2001 Tentang Pelaksanaan Tugas dan Wewenang BPSK.

Ketua BPSK memberitahukan putusan majelis secara tertulis kepada alamat konsumen dan pelaku usaha yang bersengketa, selambat-lambatnya 7 (tujuh) hari kerja sejak putusan dibacakan. Dalam waktu 14 (empat belas) hari kerja terhitung sejak putusan BPSK diberitahukan, konsumen dan pelaku usaha yang bersengketa wajib menyatakan menerima dan menolak putusan BPSK. Konsumen dan pelaku usaha yang menolak putusan BPSK dapat mengajukan keberatan kepada pengadilan negeri selambatlambatnya dalam waktu 14 (empat belas) hari kerja terhitung sejak keputusan BPSK dibacakan. Tata cara pengajuan keberatan terhadap putusan BPSK diatur dalam Peraturan Mahkamah Agung Nomor 1 Tahun 2006. Di sisi lain, pelaku usaha yang menyatakan menerima putusan BPSK, wajib melaksanakan putusan tersebut selambat-lambatnya dalam waktu 7 (tujuh) hari kerja terhitung sejak menyatakan menerima putusan BPSK. Pelaku usaha yang menolak putusan BPSK, tetapi tidak mengajukan keberatan, setelah batas waktu 7 (tujuh) hari dianggap menerima putusan dan wajib melaksanakan putusan selambat-lambatnya 5 (lima) hari kerja setelah batas waktu mengajukan keberatan dilampaui. Apabila pelaku usaha tidak menjalankan kewajibannya, maka BPSK menyerahkan putusan tersebut kepada penyidik untuk melakukan penyidikan sesuai dengan ketentuan perundang-undangan yang berlaku.

Putusan BPSK merupakan putusan yang final dan telah mempunyai kekuatan hukum yang tetap. Terhadap perbuatan BPSK, dimintakan penetapan eksekusi oleh BPSK kepada pengadilan negeri di tempat konsumen yang dirugikan. Eksekusi atau pelaksanaan sudah mengandung arti bahwa pihak yang dikalahkan tidak mau menaati putusan itu secara sukarela, sehingga putusan harus dipaksakan kepadanya dengan bantuan kekuatan hukum (R. Subekti, 1989: 130). Penetapan eksekusi diatur juga dalam Pasal 7 Perma Nomor 1 Tahun 2006 tentang Tata Cara Pengajuan Keberatan Terhadap Putusan BPSK.

Dalam Pasal 7 PERMA No 1 Tahun 2006 Tentang Tata Cara Pengajuan Keberatan Terhadap Putusan BPSK dinyatakan bahwa konsumen mengajukan permohonan eksekusi atas putusan BPSK yang tidak diajukan keberatan kepada 
pengadilan negeri di tempat kedudukan hukum konsumen yang bersangkutan atau dalam wilayah hukum BPSK yang mengeluarkan putusan. Permohonan eksekusi atas putusan BPSK yang telah diperiksa melalui prosedur keberatan, ditetapkan oleh pengadilan negeri yang memutus perkara keberatan bersangkutan.

Pengadilan negeri wajib mengeluarkan putusan atas keberatan dalam waktu paling lambat 21 (dua puluh satu) hari sejak diterimanya keberatan. Terhadap putusan pengadilan negeri tersebut, para pihak dalam waktu paling lambat 14 (empat belas) hari dapat mengajukan kasasi ke Mahkamah Agung. Mahkamah Agung wajib mengeluarkan putusan dalam waktu paling lambat 30 (tiga puluh) hari sejak menerima permohonan kasasi.

\section{PENUTUP}

Dari uraian di atas dapat disimpulkan sebagai berikut :

1. Sengketa konsumen adalah setiap perselisihan antara konsumen dengan penyedia produk konsumen (barang dan/atau jasa konsumen) yang lazim disebut dengan pelaku usaha dalam hubungan hukum satu sama lain, mengenai produk konsumen tertentu.

2. Sengketa konsumen dapat menyangkut pemberian sesuatu, berbuat sesuatu, atau tidak berbuat sesuatu sebagaimana diatur dalam Pasal 1233 Jo 1234 KUH Perdata atau dapat pula berbagai kombinasi dari prestasi tersebut.
3. Objek sengketa konsumen dalam hal ini dibatasi hanya menyangkut produk konsumen yaitu barang atau jasa yang pada umumnya digunakan untuk keperluan rumah tangganya dan tidak untuk tujuan komersial.

4. Penyelesaian sengketa konsumen dapat ditempuh melalui dua jalur, yaitu jalur pengadilan dan non pengadilan ke BPSK sebagaimana yang diatur dalam ketentuan UU No. 8 Tahun 1999 Tentang Perlindungan Konsumen.

5. Proses penyelesaian sengketa konsumen di BPSK dilakukan dengan tiga alternatif, yaitu mediasi, konsiliasi, dan arbitrase berdasarkan pilihan dan kesepakatan para pihak yang bersengketa.

6. Putusan BPSK dapat berupa: Perdamaian, gugatan ditolak dan atau gugatan dikabulkan.

7. Dalam hal gugatan dikabulkan, maka amar putusan ditetapkan kewajiban yang harus dilakukan oleh pelaku usaha. Kewajiban tersebut berupa pemenuhan: Ganti rugi; dan sanksi administratif berupa penetapan ganti rugi paling banyak Rp. 200.000.000 (dua ratus juta rupiah)

8. Putusan BPSK berupa putusan mediasi bersifat final dan mengikat para pihak, dan eksekusinya dapat dimohonkan ke Pengadilan Negeri, sedangkan putusan Arbitrase di BPSK dapat diajukan keberatan ke Pengadilan Negeri. 


\section{DAFTAR PUSTAKA}

Mahkamah Agung, PERMA No 1 Tahun 2006 Tentang Tata Cara Pengajuan Keberatan Terhadap Putusan Badan Penyelesaian Sengketa Konsumen (BPSK), Jakarta: Mahkamah Agung.

Menteri Perindustrian dan Perdagangan Republik Indonesia. 2001. Keputusan Menteri Perindustrian dan Perdagangan Republik Indonesia Nomor: $\quad 350 / \mathrm{MPP} / \mathrm{Kep} / 12 / 2001$ Tentang Pelaksanaan Tugas Dan Wewenang Badan Penyelesaian Sengketa Konsumen, Jakarta: Departemen Perindustrian dan Perdagangan
Nasution, Az. 1995. Konsumen dan Hukum. Jakarta: Pustaka Sinar Harapan

Republik Indonesia. 1999. Undangundang Nomor 8 Tahun 1999 tentang Perlindungan Konsumen, Lembaran Negara RI Tahun 1999, No. 22. Jakarta: Sekretariat Negara.

Shidarta. 2004. Hukum Perlindungan Konsumen Indonesia. Jakarta: PT. Gramedia Widiasarana Indonesia

Subekti, R. 1989. Hukum Acara Perdata. Bandung: Bina Cipta 